DOI: $10.26418 /$ positron.v10i2.41731

\title{
Nanomaterial Carbon-Dots Berbahan Dasar Daun Sirih (Piper betle L.) sebagai Antibakteri terhadap Bakteri S. mutans dan E. coli
}

\author{
Emi Kurnia Sari, Danvi Sekartaji, Athi' Nur Auliati Rahmah, dan Wipsar Sunu Brams Dwandaru* \\ Program Studi Fisika, Jurusan Pendidikan Fisika, Fakultas Matematika dan Ilmu Pengetahuan Alam, \\ Universitas Negeri Yogyakarta, Jl. Colombo No. 1, Depok, Sleman, Yogyakarta, 55281 \\ *Email: wipsarian@uny.ac.id \\ (Diterima 03 Agustus 2020; Disetujui 12 Desember 2020; Dipublikasikan 29 Desember 2020)
}

\begin{abstract}
Abstrak
Penelitian ini bertujuan untuk mensintesis, mengkarakterisasi, dan mengetahui peran nanomaterial carbon-dots (Cdots) sebagai antibakteri terhadap bakteri $S$. mutans dan E. coli. Cdots dibuat dengan bahan dasar daun sirih (Piper Betle L.) menggunakan metode pemanasan oven. Terdapat tiga buah sampel Cdots yang dihasilkan yaitu 0,5 g serbuk daun sirih+aquades (Cdots A), 0,5 g serbuk daun sirih+ekstrak daun sirih (Cdots B), dan 1 g serbuk daun sirih+ekstrak daun sirih (Cdots C). Ketiga sampel memiliki karakteristik yang hampir sama, yaitu adanya puncak absorbansi pada rentang panjang gelombang 257 $\mathrm{nm}-320 \mathrm{~nm}$. Daya serap yang tinggi pada rentang ultraviolet (UV) merupakan salah satu sifat yang dimiliki Cdots. Selain itu, ketiga sampel Cdots memiliki pendaran biru-kehijauan (cyan) ketika dikenai laser UV. Hal ini merupakan sifat luminesens Cdots yang dapat berpendar pada panjang gelombang cahaya tampak. Cdots tersusun dari core dan surface state yang masing-masing ditunjukkan dengan adanya gugus fungsi $\mathrm{C}=\mathrm{C}$ dan gugus $\mathrm{O}-\mathrm{H}$ serta $\mathrm{C}-\mathrm{O}$ yang terdeteksi oleh uji FTIR dari ketiga sampel Cdots. Pengujian antibakteri menggunakan metode Kirby-Bauer menunjukkan sampel Cdots $\mathrm{C}$ memiliki aktivitas antibakteri tertinggi karena memiliki konsentrasi Cdots yang lebih banyak dan bekerja sama dengan ekstrak sirih yang memiliki sifat antibakteri sehingga berpotensi sebagai agen antibakteri dibandingkan ekstrak daun sirih murni.
\end{abstract}

Kata kunci: antibakteri, Cdots, daun sirih, E. coli, S. mutans

\section{Latar Belakang}

Kesehatan masyarakat saat ini perlu mendapatkan perhatian karena mikroorganisme seperti bakteri dan virus yang terus bermutasi sehingga memunculkan bakteri dan virus baru. Seperti yang terjadi saat ini, virus COVID-19 muncul dan menyebabkan aktivitas manusia terganggu. Selain hidup bersih dan menjaga pola makan, menjaga rongga mulut untuk tetap bersih menjadi salah satu hal yang penting. Hal ini karena rongga mulut menjadi salah satu akses mikroba untuk masuk ke dalam tubuh.

Salah satu mikroba yang sering dijumpai dalam rongga mulut dan memiliki dampak negatif bagi tubuh manusia yaitu bakteri Streptococcus mutans ( $S$. mutans) yang termasuk dalam bakteri gram positif [1]. Selain itu, bakteri yang bersarang dalam rongga mulut dapat berasal dari makanan seperti Eschericia coli (E. coli). Bakteri ini termasuk dalam bakteri gram negatif dan dapat menyebabkan infeksi saluran pencernaan jika ikut masuk ke dalam tubuh [2]. Salah satu cara menjaga rongga mulut dari bakteri yaitu menggunakan mouthwash atau obat kumur. Mouthwash antibakteri memiliki fungsi untuk menyegarkan dan membersihkan saluran pernafasan yang digunakan dengan cara berkumur [3]. Saat ini, beberapa produk mouthwash komersial diketahui mengandung bahan herbal yang memiliki sifat antibakteri alami seperti ektrak daun sirih.

Ekstrak yang dibuat dari daun sirih (Piper betle L.) mengandung polifenol dan tanin yang berfungsi sebagai antibakteri [4]. Kandungan polifenol sangat sensitif pada bakteri gram positif [5]. Selain itu, daun sirih mengandung minyak atsiri (1,0\% sampai 4,2\%), air, protein, lemak, karbohidrat, kalsium, fosfor, vitamin A, B, C, yodium, gula, dan pati. Dalam minyak atsiri terdapat fenol alam yang mempunyai daya fungisid yang sangat kuat tetapi tidak sporosid [6]. Selain memiliki kandungan yang unggul, daun sirih juga mudah ditemukan di Indonesia dalam jumlah banyak [7]. Pembuatan ekstrak daun sirih 
biasanya menyisakan produk samping berupa limbah daun sirih yang belum dimanfaatkan.

Di sisi lain, salah satu nanomaterial yang saat ini sedang pesat dikembangkan dalam bidang nanoteknologi adalah material carbon nanodots (Cdots). Cdots merupakan nanomaterial karbon berukuran kurang dari $10 \mathrm{~nm}$ [8]. Cdots memiliki sifat unik yang tidak dimiliki material lainnya. Selain ukurannya yang sangat kecil, Cdots dapat menghasilkan emisi fluoresensi yang bergantung pada panjang gelombang eksitasinya [9]. Intensitas emisi paling tinggi terjadi ketika Cdots dikenai panjang gelombang eksitasi pada rentang ultraviolet (UV) [9]. Dengan kata lain, Cdots memiliki daya serap tinggi pada rentang panjang gelombang UV. Emisi atau pendaran Cdots yang dihasilkan berada pada rentang warna biru dan hijau [9-12]. Cdots terdiri dari bagian core atau inti yang terbentuk oleh gugus fungsi $\mathrm{C}=\mathrm{C}$ dan bagian surface state yang berikatan dengan core [13]. Surface state mengandung gugus hidroksil, karboksil, maupun amina bergantung pada pelarutnya. Selain itu, Cdots dikenal sebagai material non-toxic dan memiliki biokompatibilitas yang baik sehingga banyak dimanfaatkan dalam bio-imaging [14], drug delivery [15], dan agen antibakteri [9]. Cdots digunakan sebagai agen antibakteri pada baketeri $S$. aureus dengan memanfaatkan ukuran Cdots yang sangat kecil dan gugus amina pada surface state sehingga mampu masuk ke membran sel dan melumpuhkan bakteri tersebut [9].

Cdots dapat disintesis dari bahan organik maupun anorganik. Cdots telah berhasil disintesis menggunakan bahan dasar seperti kangkung [16], kulit luar singkong [17], daun bambu [18], dan jelaga lilin [13]. Selain itu, metode sintesis Cdots juga cukup sederhana seperti metode hydrothermal [11], microwave [11,17], dan penggorengan $[10,16]$.

Dari uraian di atas, peneliti terdorong untuk memanfaatkan sisa daun dari proses ekstraksi daun sirih sebagai prekursor Cdots dengan metode sintesis sederhana menggunakan pemanasan oven. Cdots berbahan dasar daun sirih diharapkan dapat meningkatkan aktivitas antibakteri dibandingkan dengan ekstrak murni sehingga dapat digunakan sebagai agen antibakteri dalam mouthwash antibakteri. Karakterisasi Cdots daun sirih dilakukan menggunakan spektrofotometer UV-Vis, photoluminescence (PL), dan Fourier transform infrared spectroscopy (FTIR). Selain itu, dilakukan pengujian antibakteri menggunakan metode Kirby-Bauer terhadap bekteri $S$. mutans dan E. coli untuk membuktikan adanya sifat antibakteri pada Cdots daun sirih.

\section{Metodologi}

Alat-alat yang digunakan dalam penelitian ini adalah oven, gelas ukur, timbangan digital, pipet hisap, centrifuge, termometer digital, kertas saring, mortar, cawan petri, lampu bunsen, jarum ose, jangka sorong digital, koloni counter, dan stopwatch. Karakterisasi dilakukan menggunakan laser UV (405 nm), UV-Vis, PL, dan Fourier transform infrared (FTIR). Bahan-bahan yang digunakan dalam penelitian ini adalah daun sirih, alumunium foil, aquades, bakteri $S$. mutans, dan $E$. coli.

Pembuatan ekstrak daun sirih dilakukan dengan menimbang daun sirih sebanyak $30 \mathrm{~g}$, kemudian direbus selama 1 jam pada suhu $100{ }^{\circ} \mathrm{C}$. Hasil rebusan disaring sehingga dihasilkan ekstrak daun sirih.

Selanjutnya, pembuatan Cdots dapat dijelaskan sebagai berikut. Daun sirih dari penyaringan sebelumnya dijemur untuk menghilangkan kadar air. Daun sirih yang sudah kering di oven selama 1 jam pada suhu $100{ }^{\circ} \mathrm{C}$. Daun sirih kering hasil pemanasan oven ditumbuk menggunakan mortar hingga menjadi serbuk. Kemudian, serbuk ditimbang sebanyak 0,5 g dan 1,0 g. Serbuk yang sudah ditimbang dilarutkan dalam aquades dan/atau ekstrak daun sirih sehingga didapatkan variasi sampel $0,5 \mathrm{~g}$ serbuk + aquades; 0,5 g serbuk + ekstrak daun sirih; dan $1 \mathrm{~g}$ serbuk + ekstrak daun sirih. Keseluruhan sampel diaduk merata kemudian disaring menggunakan kertas saring sebanyak dua kali penyaringan sehingga dihasilkan Cdots A $(0,5$ g serbuk + aquades $)$, Cdots B $(0,5$ g serbuk + ekstrak daun sirih), dan Cdots C (1 g serbuk + ekstrak daun sirih). Cdots A, Cdots B, dan Cdots C disentrifugasi dengan kecepatan 4000 rpm selama 5 menit untuk memisahkan cairan dan endapan yang belum tersaring sehingga didapatkan sampel yang jernih. Langkah kerja pembuatan Cdots dapat diamati pada Gambar 1.

Semua sampel Cdots dikarakterisasi menggunakan UV-Vis, PL, dan FTIR. Pengujian UVVis dilakukan di Laboratium Kimia Universitas Negeri Yogyakarta, Yogyakarta. Pengujian PL dilakukan di Laboratorium Fisika Material 


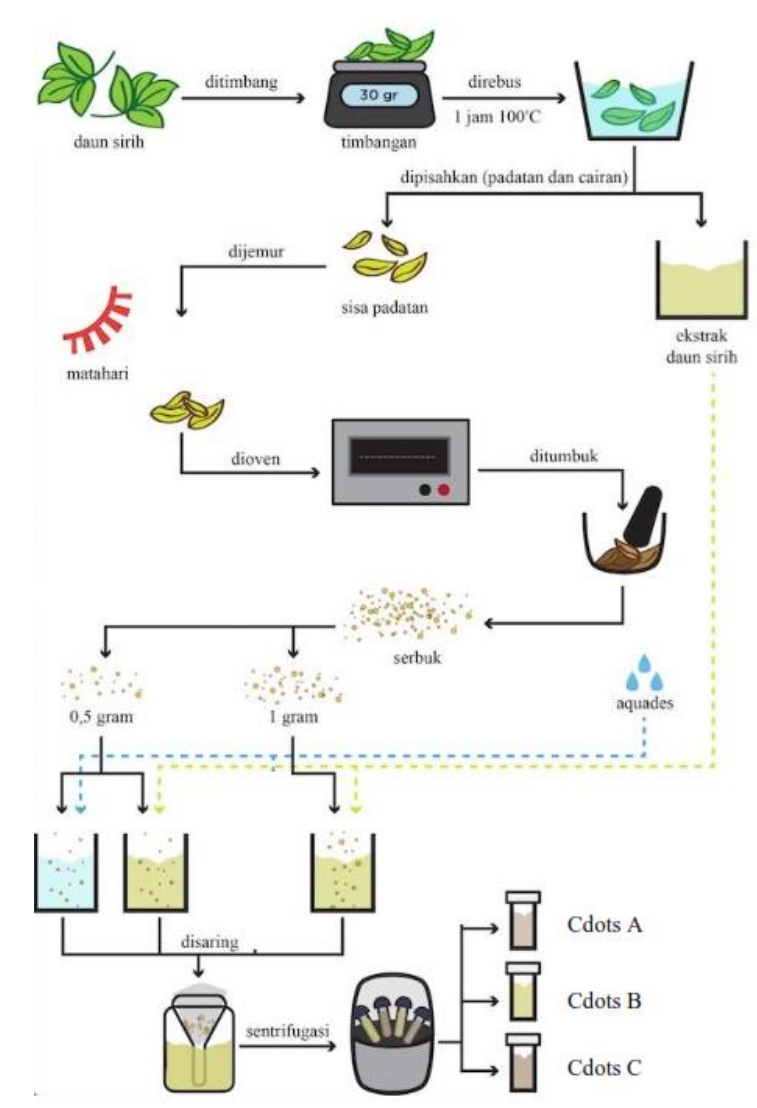

Gambar 1. Cara pembuatan Cdots daun sirih.

Universitas Gadjah Mada, Yogyakarta. Pengujian FTIR dilakukan di Laboratorium MIPA Terpadu Universitas Islam Indonesia, Yogyakarta. Sedangkan, uji antibakteri dilakukan di Laboratorium Mikrobiologi Universitas Negeri Yogyakarta. Uji antibakteri dilakukan terhadap semua sampel Cdots, ekstrak daun sirih murni, aquades (sebagai kontrol negatif), dan mouthwash komersial (sebagai kontrol positif) menggunakan metode zona hambat (zona bening) dengan mengukur daerah bening di sekitar blank disc sampel. Pengujian dilakukan selama 12 jam menggunakan bakteri S. mutans dan E. coli dan pengukuran dilakukan setiap jam.

\section{Hasil dan Pembahasan}

Larutan Cdots yang dihasilkan dari penelitian ini dapat diamati pada Gambar 2. Sintesis nanomaterial Cdots menghasilkan tiga variasi sampel, yaitu Cdots A [Gambar 2(a)], Cdots B [Gambar 2(b)], dan Cdots C [Gambar 2(c)]. Sedangkan ekstrak daun sirih sebagai pembanding dapat diamati pada Gambar 2(d). Dapat diamati pada Gambar 2 bahwa seluruh larutan Cdots berwarna kecoklatan. Namun, larutan Cdots dalam ekstrak daun sirih terlihat lebih pekat. Selain itu,

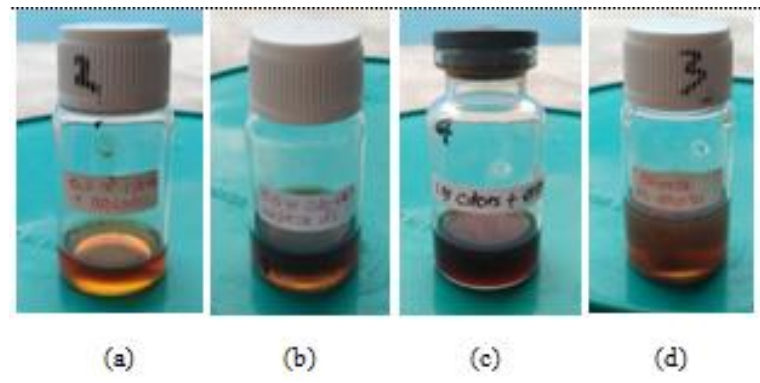

Gambar 2. Larutan Cdots A (a), Cdots B (b), Cdots C (c), dan sampel ekstrak daun sirih (d).

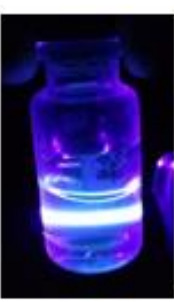

(a)

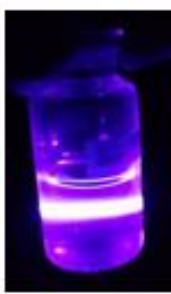

(b)

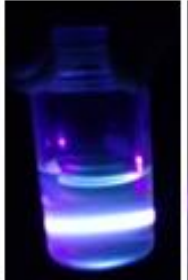

(c)

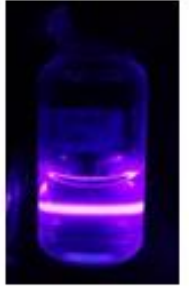

(d)
Gambar 3. Pendaran Cdots untuk Cdots A (a), Cdots B (b), Cdots C (c), dan ekstrak daun sirih (d).

kenampakan warna larutan Cdots A dan ekstrak daun sirih murni tidak terlalu berbeda.

Pengujian pertama dilakukan secara sederhana menggunakan laser UV. Salah satu indikator kualitatif eksistensi Cdots di dalam larutan adalah terjadinya pendaran akibat paparan laser UV. Hal ini dapat diamati pada Gambar 3. Untuk semua larutan Cdots (Gambar 3(a-c)), pendaran akibat pemaparan laser UV berwarna biru-kehijauan (cyan). Sampel Cdots A, Cdots B, dan Cdots $C$ tampak memiliki perbedaan pada tingkat intensitasnya. Intensitas pendaran tertinggi terjadi pada sampel Cdots C, selanjutnya Cdots A, dan terakhir Cdots B. Sedangkan sampel ekstrak daun sirih terlihat berpendar warna merah [Gambar 3(d)] yang berbeda dengan ketiga pendaran larutan Cdots.

Hasil karakterisasi UV-Vis sebagaimana ditunjukkan pada Gambar 4 merupakan grafik absorbansi terhadap panjang gelombang untuk keempat sampel. Keseluruhan sampel menunjukkan adanya dua puncak absorbansi. Pada Gambar 4(a), Cdots A (garis biru) memiliki puncak absorbansi pada panjang gelombang $257 \mathrm{~nm}$ dan $320 \mathrm{~nm}$, Cdots B (garis putus-putus merah) memiliki puncak absorbansi pada panjang gelombang $281 \mathrm{~nm}$ dan $320 \mathrm{~nm}$, sedangkan ekstrak daun sirih murni (garis ungu) menunjukkan puncak absorbansi pada panjang gelombang $287 \mathrm{~nm}$ dan $320 \mathrm{~nm}$. Dua puncak 
absorbansi larutan Cdots $\mathrm{C}$ berada pada panjang gelombang $278 \mathrm{~nm}$ dan $316 \mathrm{~nm}$ (Gambar 4(b)). Selain itu, grafik pada Gambar 4(b) terlihat terpotong karena sampel Cdots $\mathrm{C}$ yang diujikan terlalu pekat sehingga absorbansinya sangat tinggi dan tidak dapat terdeteksi oleh spektrofotometer UV-Vis.

Puncak absorbansi pada grafik UV-Vis tersebut menunjukkan semua sampel mengalami transisi elektronik (eksitasi) akibat menyerap energi dari panjang gelombang UV. Penyerapan tersebut terjadi karena energi dari sinar UV pada panjang gelombang tertentu sama dengan energi eksitasi dari elektron sampel. Transisi elektronik yang terjadi merupakan eksitasi elektron pada tingkat energi dasar (HOMO) ke arah tingkat energi yang lebih tinggi (LUMO) [10]. Pada sampel Cdots, puncak pertama merupakan transisi $\pi-\pi^{*}$ serta adanya struktur konjugasi pada Cdots (merepresentasikan core) dan puncak kedua merupakan transisi $\mathrm{n}-\pi^{*}$ (merepresentasikan surface state)[11,19]. Selain itu, semakin tinggi nilai absorbansi maka semakin banyak Cdots yang terbentuk dalam sampel.

Berdasarkan penelitian sebelumnya, Cdots yang telah disintesis memiliki puncak absorbansi pada panjang gelombang $235 \mathrm{~nm}$ sampai $360 \mathrm{~nm}$ atau pada rentang panjang gelombang UV $[10,20,21]$. Dengan demikian, ketiga sampel Cdots telah berhasil disintesis karena memiliki puncak absorbansi pada panjang gelombang $257 \mathrm{~nm}$ sampai $320 \mathrm{~nm}$.

Grafik hasil UV-Vis dari ketiga sampel Cdots terlihat memiliki kesamaan dengan ekstrak murni, tetapi terdapat perbedaan pada panjang gelombang puncak pertama. Dapat diamati adanya pergeseran panjang gelombang pada puncak absorbansi, yakni blue shift. Terbentuknya Cdots ini ditandai dengan terjadinya pergeseran ke arah panjang gelombang yang pendek, yakni dari 287 nm (ekstrak murni) menjadi $281 \mathrm{~nm}$ (Cdots B), 257 nm (Cdots A), dan 278 nm (Cdots C).

Karakterisasi PL dilakukan untuk mengetahui sifat luminesens dari Cdots. Karakterisasi PL dilakukan pada tiga sampel Cdots dan satu ekstrak daun sirih murni menggunakan panjang gelombang eksitasi $405 \mathrm{~nm}$. Hasil karakterisasi PL dapat dilihat pada Gambar 5. Gambar 5 menunjukkan ketiga sampel Cdots memiliki profil serta puncak intensitas pada panjang gelombang yang sama. Puncak intensitas pada panjang

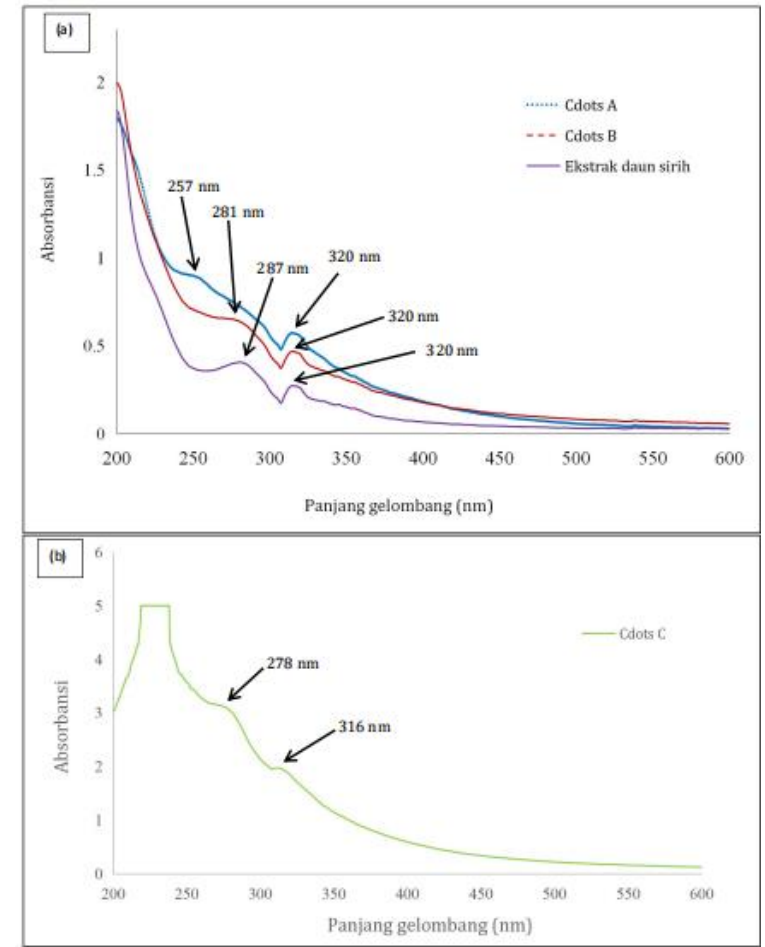

Gambar 4. Hasil Karakterisasi UV-Vis pada sampel larutan Cdots A, Cdots B, ekstrak murni (a), dan Cdots C (b).

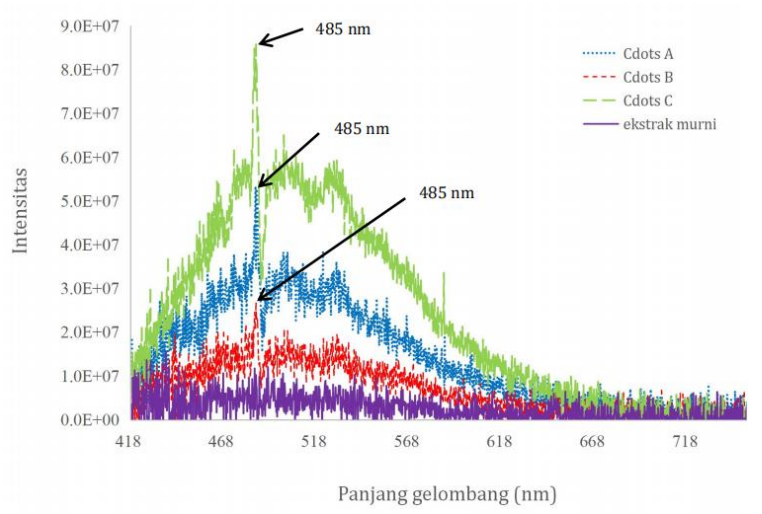

Gambar 5. Hasil karakterisasi PL.

gelombang warna tampak (visible) menunjukkan adanya pendaran yang dihasilkan oleh sampel Cdots. Ketiga sampel Cdots memiliki puncak intensitas pada panjang gelombang $485 \mathrm{~nm}$, dimana panjang gelombang tersebut termasuk dalam rentang panjang gelombang warna biru atau lebih tepatnya cyan (450-495 nm) sehingga dapat disimpulkan bahwa Cdots yang disintesis seluruhnya memendarkan warna cyan. Hal ini sesuai dengan berbagai penelitian sebelumnya [912] yang menghasilkan warna pendaran Cdots pada rentang warna biru sampai hijau. Gambar 5 juga menunjukkan sampel ekstrak daun sirih murni (garis warna ungu) tidak memiliki puncak 
intensitas sehingga dapat disimpulkan bahwa ekstrak daun sirih tidak mengandung Cdots.

Hasil karakterisasi PL sesuai dengan Gambar 3 yang menampilkan sampel Cdots menghasilkan pendaran berwarna cyan ketika disinari laser UV. Sedangkan, pendaran warna merah pada sampel ekstrak daun sirih murni tidak terdeteksi pada hasil PL. Selain itu, dari gafik PL dapat diamati bahwa Cdots dengan massa serbuk sama dalam pelarut yang berbeda memiliki intensitas PL yang berbeda, dimana Cdots A (dalam pelarut aquades) memiliki tingkat intensitas yang lebih tinggi dibandingkan Cdots B (dalam larutan ekstrak daun sirih). Di sisi lain, Cdots dalam pelarut yang sama tetapi massa serbuk berbeda juga menghasilkan intensitas PL yang berbeda, yakni Cdots C (1 g serbuk) memiliki intensitas PL yang lebih tinggi dibandingkan Cdots B (0,5 g serbuk). Oleh karena itu, intensitas pendaran Cdots dipengaruhi oleh massa serbuk yang dilarutkan dan juga jenis pelarutnya. Semakin banyak serbuk yang dilarutkan, maka Cdots yang terbentuk akan semakin banyak. Sedangkan jenis pelarut akan berpengaruh pada terbentuknya surface state yaitu gugus fungsi yang berikatan dengan inti Cdots.

Karakterisasi terakhir telah dilakukan pada ketiga sampel Cdots untuk mengetahui gugus fungsi yang terkandung dalam sampel. Hasil karakterisasi FTIR dapat diamati pada Gambar 6. Karakteristik FTIR dari semua sampel Cdots memiliki pita-pita gugus fungsi yang sama. Gambar 6 menunjukkan adanya gugus fungsi hidroksil (O$\mathrm{H})$ untuk band pada panjang gelombang $3441 \mathrm{~cm}^{-1}$; $3438 \mathrm{~cm}^{-1}$; dan $3440 \mathrm{~cm}^{-1}$ masing-masing untuk sampel Cdots A, Cdots B, dan Cdots C. Selain itu, terdapat gugus $\mathrm{C}-\mathrm{O}$ untuk band pada panjang gelombang $2063 \mathrm{~cm}^{-1}$; $2073 \mathrm{~cm}^{-1}$; dan $2082 \mathrm{~cm}^{-1}$ masing-masing untuk sampel Cdots $A$, Cdots $B$, dan Cdots C. Selanjutnya, terdapat gugus $\mathrm{C}=\mathrm{C}$ untuk

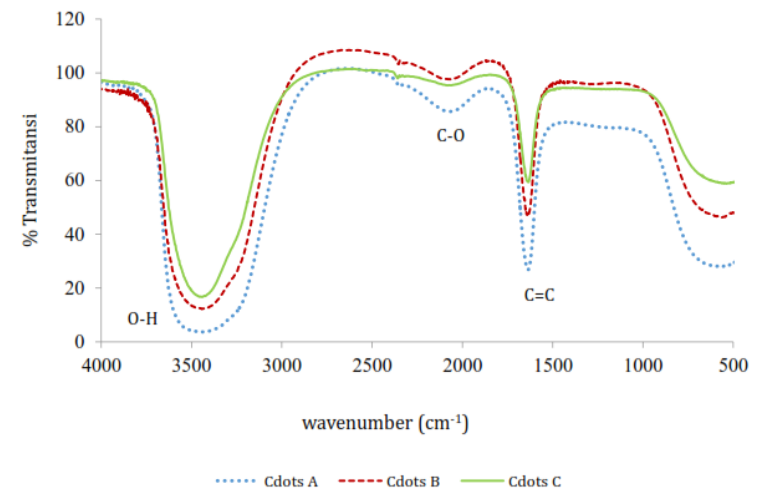

Gambar 6. Hasil Karakterisasi FTIR. band pada panjang gelombang $1633 \mathrm{~cm}^{-1} ; 1635$ $\mathrm{cm}^{-1}$; dan $1634 \mathrm{~cm}^{-1}$ masing-masing untuk sampel Cdots A, Cdots B, dan Cdots C. Hasil uji FTIR pada ketiga sampel Cdots sesuai dengan penelitian sebelumnya [20]. Penelitian tersebut telah berhasil mensintesis Cdots dengan gugus fungsi yang terbentuk adalah $\mathrm{O}-\mathrm{H}, \mathrm{C}-\mathrm{O}$, dan $\mathrm{C}=\mathrm{C}$ yang masingmasing berada pada rentang panjang gelombang $3200 \mathrm{~cm}^{-1}$ sampai $3600 \mathrm{~cm}^{-1} ; 2065 \mathrm{~cm}^{-1}$ sampai $2080 \mathrm{~cm}^{-1}$; dan $1610 \mathrm{~cm}^{-1}$ sampai $1680 \mathrm{~cm}^{-1}$. Gugus $\mathrm{C}=\mathrm{C}$ merupakan penyusun core, sementara gugus O-H dan C-O merupakan bagian surface state dari sampel Cdots [10]. Dari gafik pada Gambar 6 juga dapat diamati bahwa Cdots A memiliki transmitansi yang lebih rendah dibandingkan sampel Cdots B dan Cdots C.

Untuk mengetahui peran Cdots sebagai antibakteri, dilakukan uji antibakteri selama 12 jam dan pengukuran diameter zona hambat dilakukan setiap jam. Hasil uji antibakteri dengan bakteri $S$. mutans dapat diamati pada Gambar 7 . Dari setiap sampel dihasilkan diameter zona hambat yang berbeda seperti yang terlihat pada Gambar 7. Selanjutnya, dari hasil uji antibakteri didapatkan grafik aktivitas antibakteri setiap sampel (Gambar 8). Dapat dilihat pada Gambar 8(a), sampel Cdots C menunjukkan aktivitas antibakteri tertinggi dengan diameter zona hambat terbesar, yaitu $8,4 \mathrm{~mm}$ pada jam kelima. Selain itu, sifat antibakteri dari Cdots $C$ terlihat efektif pada jam kelima hingga jam kesembilan. Sampel lainnya (Cdots A, Cdots B, ekstrak murni, dan mouthwash komersial) menunjukkan aktivitas antibakteri yang hampir sama dengan diameter terbesar 7,1 mm pada jam kelima dan selanjutnya mengalami fluktuasi. Sedangkan aquades tidak memiliki zona hambat. Berdasarkan Gambar 8, aktivitas antibakteri pada Cdots $\mathrm{C}$ lebih baik dibandingkan mouthwash komersial. Hal ini dimungkinkan zat antibakteri dari ekstrak daun

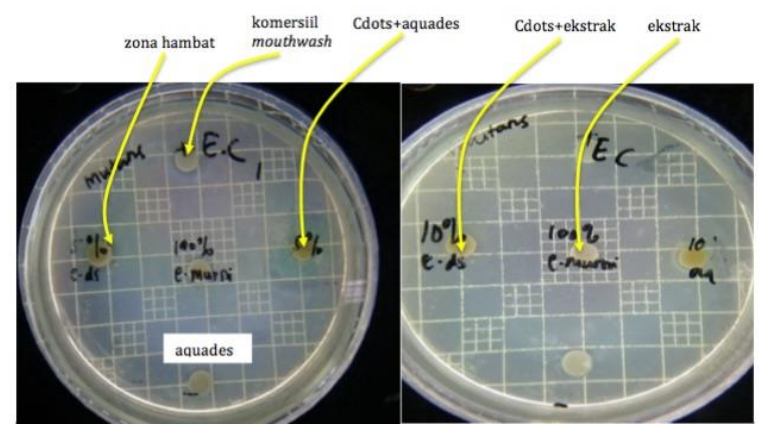

Gambar 7. Hasil Uji antibakteri terhadap bakteri S. mutans. 


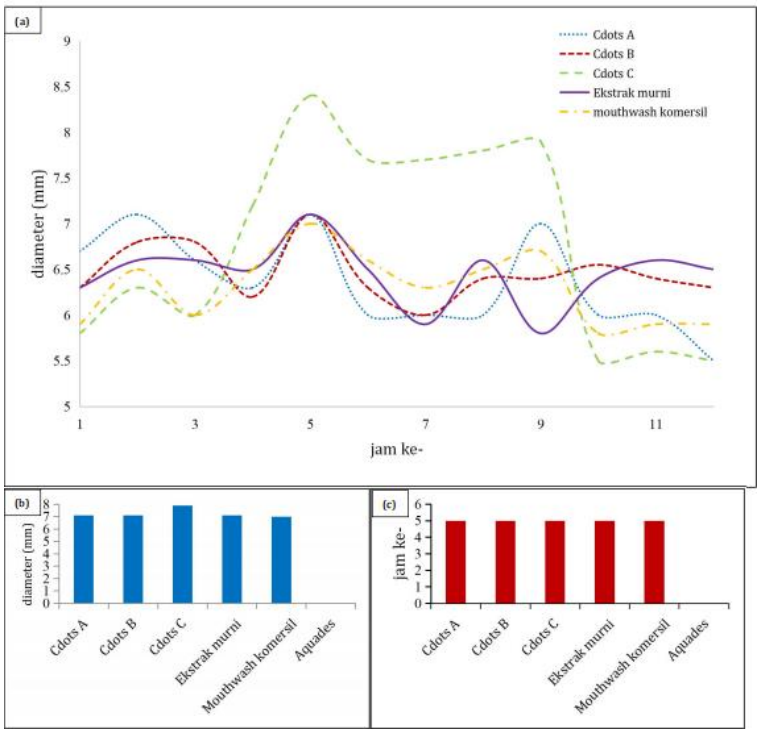

Gambar 8. Aktivitas antibakteri setiap sampel terhadap bakteri $S$. mutans (a), perbandingan diameter terbesar yang dicapai setiap sampel (b), dan perbandingan jam efektif setiap sampel yaitu saat mencapai diameter tertinggi (c).

sirih berikatan dengan core Cdots membentuk surface state dan dengan ukurannya yang sangat kecil, Cdots berperan sebagai transport zat antibakteri tersebut menuju bakteri $S$. mutans. Oleh karena itu, semakin banyak Cdots yang terbentuk dalam ektrak daun sirih maka semakin tinggi aktivitas antibakteri.

Uji antibakteri juga dilakukan terhadap bakteri E. coli dengan durasi pengukuran selama 12 jam. Hasil dari uji antibakteri menggunakan $E$. coli dapat diamati pada Gambar 9. Grafik pada Gambar 10(a) menunjukkan aktivitas antibakteri pada sampel Cdots A, Cdots B, Cdots C, ekstrak daun sirih, aquades dan mouthwash komersial terhadap bakteri E. coli. Dari grafik tersebut, mouthwash komersial memiliki diameter zona hambat terbesar, yakni 10,6 mm pada jam kedua lalu mengalami penurunan dan naik kembali pada jam kesepuluh. Sampel aquades tidak memiliki zona hambat. Diantara ketiga sampel Cdots dan sampel ekstrak daun sirih, Cdots C memiliki diameter zona hambat tertinggi yaitu $8,7 \mathrm{~mm}$ pada jam keenam dengan aktivitas antibakteri terbaik terjadi pada jam keempat hingga keenam. Sedangkan sampel lain memiliki zona hambat tertinggi pada jam kedua dan mengalami penurunan terutama pada sampel ekstrak murni yang tidak lagi memiliki diameter zona hambat terhadap E. coli mulai jam kesepuluh. Meskipun nilai zona hambat Cdots $\mathrm{C}$ masih di bawah

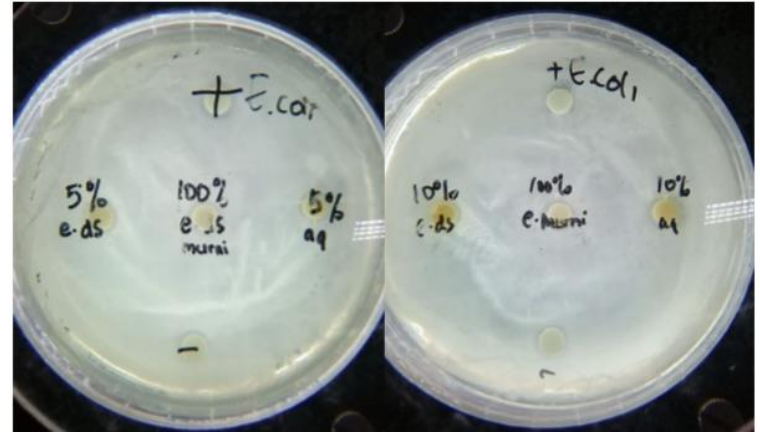

Gambar 9. Hasil uji antibakteri menggunakan bakteri E. coli.

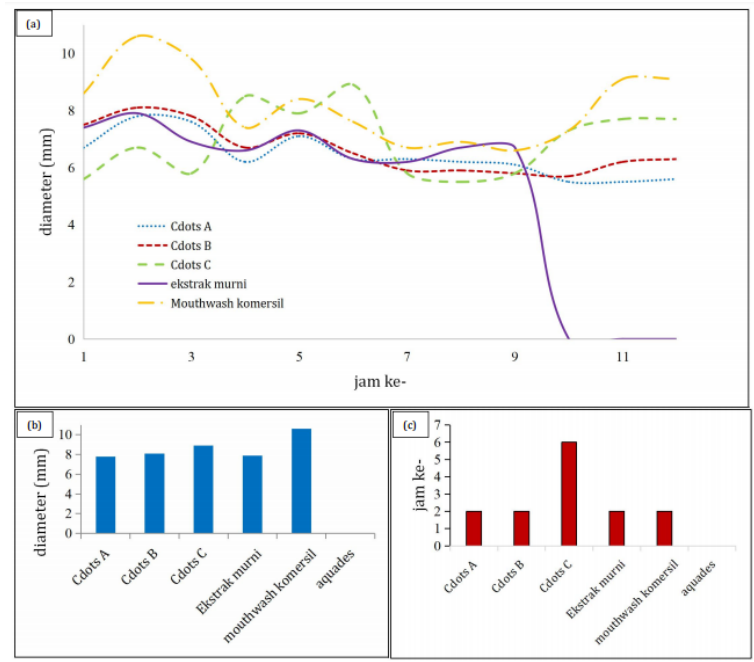

Gambar 10. Aktivitas antibakteri setiap sampel terhadap bakteri E. coli (a), perbandingan diameter terbesar yang dicapai setiap sampel (b), dan perbandingan jam efektif setiap sampel yaitu saat mencapai diameter tertinggi (c).

mouthwash komersial, tetapi sama halnya dengan penjelasan sifat antibakteri terhadap S. mutans, kombinasi antara Cdots dengan ekstrak daun sirih terbukti berpotensi sebagai antibakteri terhadap bakteri E. coli.

\section{Kesimpulan}

Dalam artikel ini telah dilaporkan pembuatan Cdots berbahan dasar daun sirih dengan metode pemanasan oven. Sintesis Cdots daun sirih menghasilkan tiga variasi sampel yaitu Cdots A (0,5 g serbuk sirih + aquades $)$, Cdots B $(0,5 \mathrm{~g}$ serbuk sirih + ekstrak), dan Cdots C (1 g serbuk sirih + ekstrak), serta sampel ekstrak murni sebagai pembanding. Ketiga sampel Cdots menunjukkan sifat optik seperti mempunyai daya serap yang tinggi (absorbansi) pada rentang panjang gelombang 257-320 nm yang merupakan daerah panjang gelombang UV, dan dapat 
memendarkan warna biru-kehijauan atau cyan. Terbentuknya Cdots dalam sampel diperkuat dengan adanya gugus fungsi $\mathrm{C}=\mathrm{C}$ sebagai penyusun core dan $\mathrm{O}-\mathrm{H}, \mathrm{C}-\mathrm{O}$, sebagai penyusun surface state pada Cdots. Uji antibakteri di dalam media yang ditanami bakteri $S$. mutans maupun bakteri $E$. coli menunjukkan sampel Cdots $\mathrm{C}$ memiliki tingkat aktivitas antibakteri tertinggi sehingga Cdots $\mathrm{C}$ (Cdots di dalam ekstrak daun sirih) berpotensi sebagai agen antibakteri dibanding ektrak daun sirih murni. Oleh karena itu, Cdots daun sirih dapat dimanfaatkan sebagai bahan antibakteri pada produk mouthwash.

\section{Ucapan Terima Kasih}

Para penulis mengucapkan terimakasih kepada Fakultas Matematika dan Ilmu Pengetahuan Alam yang telah mendukung penelitian ini.

\section{Daftar Pustaka}

[1] Mahmudah, F. dan Sri, A., Uji Aktivitas Antibakteri dari Ekstrak Etanol Temukunci, Jurnal Penelitian Saintek, 22(1), pp. 59-66, 2017.

[2] Irianto, K., Mikrobiologi Menguak Dunia Mikroorganisme, Jilid 1, Yrama Widya, 2006.

[3] Putra, A., Formulasi Obat Kumur dari Ekstrak Daun Sirih Hijau ( Piper betle L) dan Ekstrak Daun Jambu Biji ( Psidium guajava L) dengan Pelarut Etanol $96 \%$ dan Tambahan Peppermint, Diploma thesis, Jurusan Farmasi dan Kesehatan, Institut Kesehatan Helvetia Medan, Medan, 2018.

[4] Nurdianti, L., Annissya, W. F., Pamela, Y. M., Novianti, E., Audina M., dan Kurniasari E., Formulasi Sediaan Pasta Gigi Herbal Kombinasi Ekstrak Daun Sirih (Piper Betle L.) dan Kulit Buah Jeruk Lemon (Citrus Limon Burm F.) sebagai Pemutih dan Antiseptik pada Gigi, Jurnal Kesehatan Bakti Tunas Husada, 16(1), pp. 177-187, 2016.

[5] Pambayun, R., Gardjito, M., Sudarmadhi, S., dan Kuswanto, K. R., Kandungan fenol dan sifat antibakteri dari berbagai jenis ekstrak produk gambir (Uncaria gambir Roxb), Majalah Farmasi Indonesia, 18(3), pp. 141 146, 2007.

[6] Soemiati, A. dan Elya, B., Uji Pendahuluan Efek Kombinasi Anti Jamur Infus dan Sirih ( $P$. betle), Kulit Buah Delima (Punica ganatum L.), dan Rimpang Kunyit (Curcuma domestica Val.) terhadap Jamur Candida albicans, Makara Seri Sains, 6(3), pp. 149-150, 2002.
[7] Ribuan Tanaman Herbal di Indonesia Belum Dimanfaatkan Secara Optimal, https://www.ugm.ac.id/id/newsPdf (Diakses pada 5 April 2019).

[8] Wang, Y. dan Hu, A., Carbon Quantum Dots: Synthesis, Properties, and Applications, Journal of Materials Chemistry C, 2(34), p. 6921, 2014

[9] Yang, J., Zhang, X., Ma, Y.-H., Gao, G., Chen, X., Jia, H.-R., Li, Y.-H., Chen, Z. dan Wu, F.-G., Carbon Dot-based Platform for Simultaneous Bacterial Distinguishment and Antibacterial Applications, ACS Appl. Mater. Interfaces, 8(47), pp. 32170-32181, 2016.

[10] Dwandaru, W. S. B., Fadli, A. L., Sari, E. K. dan Isnaeni, Cdots and Cdots/S Synthesis from Nam-Nam Fruit (Cyanometra cauliflora L.) via Frying Method using Cooking Oil, Digest Journal of Nanomaterials and Biostructures, 15(2), pp 555-560, 2020.

[11] Dwandaru, W. S. B., Bilqis, S. M., Wisnuwijaya, R. I. dan Isnaeni, Optical Properties Comparison of Carbon Nanodots synthesized from Commercial Granulated Sugar using Hydrothermal Method and Microwave, Material Research Express, 6, p. 105041, 2019.

[12] Zhou, J., Sheng, Z., Han, H., Zou, M. dan Li, C., Facile Synthesis of Fluorescent Carbon Dots using Watermelon Peel as a Carbon Source, Materials Letters, 66, pp. 222-224, 2012.

[13] Liu, H., Ye, T. dan Mao, C., Fluorescent Carbon Nanoparticles Derived from Candle Soot, Angew. Chem. Int. Ed., 46, pp. 6473 -6475, 2007.

[14] Zheng, M., Ruan, S. B., Liu, S., Sun, T. T., Qu, D., Zhao, H. F., Xie, Z. G., Gao, H. L., Jing, X. B. dan Sun, Z. C., Self Targeting Fluorescent Carbon Dots for Diagnosis of Brain Cancer Cells. ACS Nano, 9, pp. 11455-11461, 2015.

[15] Gong, X. J., Zhang, Q. Y., Gao, Y. F., Shuang, S. M., Choi, M. dan Dong, C., Phosphorus and Nitrogen Dual-Doped Hollow Carbon Dot as a Nanocarrier for Doxorubicin Delivery and Biological Imaging, ACS Appl. Mater. Interfaces, 8, pp. 11288-11297, 2016.

[16] Dwandaru, W. S. B., Fauzi, F., Sari, E. K., Santoso, I. dan Suhendar, H., Optical Properties Comparison of Carbon Nanodots Synthesized from Kangkung (Ipomoea aquatica) with Deep Frying and Roasting Techniques, Jurnal Penelitian Fisika dan Aplikasinya, 9, pp. 123-131, 2019. 
[17] Putro, P. A., Roza, L. dan Isnaeni, Karakterisasi Sifat Optik C-Dots dari Kulit Luar Singkong Menggunakan Teknik Microwave, Jurnal Teknologi Technoscientia, 11(2), pp. 128-134, 2019.

[18] Fahmi, M. Z., Haris, A., Permana, A. J., Wibowo, D. L. N., Purwnato, B., Nikmah, Y. L. dan Idris, A., Bamboo Leaf-based Carbon Dots for Efficient Tumor Imaging and Therapy, RSC Adv., 8, pp. 38376-38383, 2018.

[19] Nisa, A. K., Sintesis Nanopartikel Karbon Berfluoresens, Skripsi, Prodi Kimia, Institut Teknologi Bandung, Bandung, 2014.
[20] Li, C.-L., Ou, C.-M., Huang, C.-C., Wu, W.-C., Chen, Y.-P., Lin, T.-E., Ho, L.-C., Wang, C.-W., Shih, C.-C., Zhou, H.-C., Lee, Y.-C., Tzeng, W.-F., Chiou, T.-J., Chu, S.-T., Cang, J. dan Chang, H.T., Carbon Dots Prepared From Ginger Exhibiting Efficient Inhibition of Human Hepatocellular Carcinoma Cells, Journal of Material Chemistry B, 2, pp. 4564-4571, 2014.

[21] Yang, Z., Xu, M., Liu, Y., He, F., Gao, F., Su, Y., Wei, H. dan Zhang, Y., Nitrogen-doped, Carbon-rich, Highly Photolumescent Carbon Dots from Ammonium Citrate, Nanoscale, 6, pp. 1890-1895, 2014. 